\title{
ANALISIS CAR, NPF, BOPO DAN FDR UNTUKMENGUKUR TINGKAT KESEHATAN, SERTA PENGARUHNYA TERHADAPROA ( Studi Kasus Pada Bank Umum Syariah/BUSYangTerdaftardi BEI )
}

\author{
ITA DARSITA \\ Staf Pengajar Fakultas Ekonomi Universitas Pamulang \\ Email: dosen02235@unpam.ac.id
}

\begin{abstract}
ABSTRAK
Penelitian ini bertujuan menganalisis CAR, NPF, BOPO dan FDRuntuk mengukur tingkat kesehatan, serta pengaruhnya terhadap ROA (studi kasus pada BUS yang terdaftar di BEI). Data yang digunakan dalam penelitian ini diperoleh dari data laporan keuangan publikasi tahunan Bank Umum Syariah periode 2010-2016.Populasi dalam penelitian ini adalah duabelas Bank Umum Syariah di Indonesia yang terdaftar di Bursa Efek Indonesia. Setelah melewati tahap purposive sampling, terdapat enam sampel Bank Umum Syariah yang layak digunakan yaitu Bank Muamalat Indonesia, Bank Syariah Mandiri, Bank Syariah Bukopin, Bank BRI Syariah, Bank Mega Syariah dan Bank Panim Dubai Syariah Tbk. Teknik analisis yang digunakan dalam penelitian ini adalah analisis kuantitatif dengan rasio keuangan dan analisis regresi linear berganda yang bertujuan untuk memperoleh kriteria tingkat kesehatan dan gambaran yang menyeluruh mengenai hubungan antara variable dan proses perhitungan statistik dengan menggunakan program eviews versi 8.Sedangkan uji asumsi klasik yang digunakan dalam penelitian ini meliputi uji normalitas, uji multikolonieritas, uji heteroskedastisitas dan uji autokorelasi.

Hasil penelitian tingkat kesehatan Bank Umum Syariah periode 2010 - 2016 menunjukan rasio CAR dengan kriteria sangat sehat, rasio FDR dengan kriteria sehat, rasio ROA dan NPF dengan kriteria cukup sehat dan rasio BOPO dengan kriteria kurang sehat serta hasil penelitianuji-t/parsial menunjukkan bahwa CAR tidak berpengaruh negatif terhadap ROA dan tidak signifikan, NPF tidak berpengaruh negatif terhadap ROA dan tidak signifikan, BOPO berpengaruh negatif terhadap ROA dan signifikan, FDR berpengaruh positif terhadap ROA dan signifikan. Sedangkan penelitian uji-F/Simultan CAR, NPF, BOPO dan FDR bersama-sama berpengaruh terhadap ROA dan signifikan. Kemampuan prediksi dari keempat variabel tersebut terhadap ROA sebesar $75,26 \%$ sedangkan sisanya $24,74 \%$ dipengaruhi oleh faktor lain di luar model penelitian. Hasil penelitian ini diharapkan dapat menjadi pedoman bagi manajemen Bank Umum Syariah dalam mengelola perusahaan.

Kata Kunci: Analisis CAR,NPF,BOPO dan FDR untuk mengukur tingkat kesehatan, serta pengaruhnya terhadapROA.
\end{abstract}

\section{ABSTRACT}

The purpose of this research was to analyze CAR, NPF, BOPO, and FDR to measure the good level, and the effect to the ROA (THE STUDY CASE in BUS which was registered in $B E I)$. The data which were used in this research got from the annual finance public report's data of Syari'ah Public Bank period 2010-2016. The population in this research were twelve of Syari'ahPublic Bank which were registered in "Indonesia Effect Stock Exchanged". After I passed the step of Sampling Purposive, there were six samples of Syari'ah Public Bank 


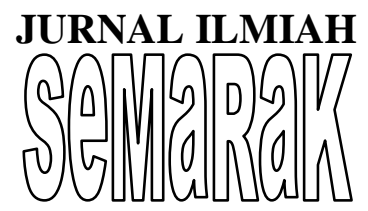

P-ISSN 2615-6849, E-ISSN 2622-3686

Jurnal Semarak,Vol. 3,No.1, Februari 2020, Hal (93- 110)

@Prodi Manajemen Fakultas Ekonomi Universitas Pamulang

which proper used i.e. Bank Muamalat Indonesia, Bank Syari'ahMandiri, Bank Syari'ahBukopin, Bank BRI Syari'ah, Bank Mega Syari'ah and Bank Panin Dubai Syari'ahTbk. The analysis technique that used in this research was quantitative analysis with finance ratio and multiple linear regression analysis which to get the criteria of good level and the whole illustration about relation between variable and the statistics calculation process by using Eviews version 8 program. Meanwhile this research used classical assumption test including normality test, multikolonieritas test, heteroskedastisitas test and auto correlation test.

The good level result's of Syari'ah Public Bank period 2010-2016 showed CAR ratio was on the best criteria, FDR ratio was on the best criteria, ROA and NPF ratio were on average good and BOPO ratio on the worst criteria; the result of this research by using $t$ partialtest showed that CAR did not give negative effect to ROA and also did not significant. Whereas F-Simultaneous Test of this research CAR, NPF, BOPO, and FDR togetherness gave the effect to ROA and significant. The prediction capability of those four variables to ROA 75,26\% meanwhile the rest 24,74\% were influenced by another factor in this research model. Hopefully the result of this research can be as a compass for Syari'ah Public Bank management in order to manage the company.

Keywords :CAR Analysis, NPF, BOPO, and FDR to measure the good level and theeffect to $R O A$

\section{PENDAHULUAN}

\section{A. Latar Belakang Masalah}

Perkembangan kelembagaan bank umum syariah menunjukkan bahwa dilakukannya amandemen UU No. 7 tahun 1992 menjadi UU No. 10 tahun 1998 direspon positif oleh pelaku industri perbankan dengan adanya penambahan satu Bank Umum Syariah dan 1 UnitUsaha Syariah, serta 69 BPRS pada tahun 1999. Bank Syariah telah tersebar hampir di seluruh kota yang berada di Indonesia. Berdasarkan data statistik perbankan syariah yang dikeluarkan oleh Otoritas Jasa Keuangan (OJK), sampai dengan bulan Januari 2015 jumlah Bank Umum Syariah di Indonesia adalah sebanyak 12 Bank Umum Syariah dengan jumlah kantor sebanyak 2,145 kantor yang tersebar di seluruh Indonesia. Pertumbuhan jumlah Bank Umum Syariah ini bisa dikatakan cukup signifikan dari tahun 2009 yang masih berjumlah 711 kantor.
Eksistensi Bank Umum Syariah juga didorong oleh tingginya minat masyarakat untuk menempatkan dananya di Bank Umum Syariah karena produk dana perbankan syariah memiliki daya tarik bagi deposan mengingat nisbah bagi hasil dan margin produk tersebut masih kompetitif dibanding bunga di bank konvensional (LPPS, 2009). Selain itu, kinerja perbankan syariah menunjukkan peningkatan yang signifikan cermin dari permodalan dan profitabilitas yang semakin meningkat (LPPS, 2010).

Selain itu, bank harus menperhatikan tingkat kesehatan bank agar selalu terpelihara karena bank mengandalkan kepercayaan nasabah dalam kegiatan usahanya (Merkusiwati, 2007 dalam Ponco, 2008). Tingkat kesehatan bank dapat dilihat melalui beberapa indikator atau alat ukur. Salah satu indikator tersebut adalah laporan keuangan bank yang dapat digunakan menjadi dasar penilaian. Di dalam laporan keuangan dapat dihitung melalui 
beberapa rasio keuangan yang biasanya dijadikan sebagai dasar penilaian tingkat kesehatan bank dan nantinya hasil tersebut akan dijadikan alat untuk mengestimasikan beberapa hubungan kunci serta kecendrungan yang dapat memberikan dasar pertimbangan mengenai potensi keberhasilan perusahaan dimasa yang akan datang (Almilia dan Herdiningtyas, 2005 dalam Almadany, 2012).

Kinerja keuangan suatu bank juga mencerminkan tingkat kesehatan bank tersebut. Dalam Surat Edaran BI No. 9/24/DPbs disebutkan penilaian tingkat kesehatan bank dipengaruhi oleh faktor CAMELS (Capital, Asset Quality, Management, Earnings, Liquidity, Sensitivity to Market Risk). Aspek Capital meliputi Kewajiban Penyediaan Modal Minimum (KPMM) atau Capital Adequacy Ratio (CAR), aspek Asset Quality meliputi Non Performing Financing (NPF), aspek Earnings meliputi Return On Equity (ROE), Return On Asset (ROA), dan Operational Efficiency Ratio (BOPO), dan aspek Liquidity meliputi Financing to Deposit Ratio (FDR).

Alasan dipilihnya Return OnAsset (ROA) sebagai rasio adalah karena ROA digunakan untuk mengukur kemampuan manajemen bank dalam memperoleh keuntungan secara keseluruhan. Dendawijaya (2003) menambahkan semakin besar ROA bank, semakin besar pula tingkat keuntungan yang dicapai bank tersebut dan semakin baik pula posisi bank tersebut dan segi penggunaan aset.

Modal (Capital) merupakan salah satu variabel yang dapat digunakan sebagai dasar pengukuran kinerja bank. Besarnya suatu modal suatu bank, akan mempengaruhi tingkat kepercayaan masyarakat terhadap kinerja bank. Penetapan Capital Adequacy Ratio(CAR) sebagai variabel yang mempengaruhi profitabilitas didasarkan hubungannya dengan tingkat risiko bank. Tingginya rasio capital dapat melindungi nasabah, sehingga dapat meningkatkan kepercayaan nasabah terhadap bank (Wedaningtyas, 2002 dalam Ponco, 2008).

CAR menjelaskan sampai dimana penurunan asset bank masih bisa ditutupi dengan ekuitas bank yang dimiliki, semakin besar nilai CAR maka menunjukkan kondisi sebuah bank itu semakin baik (Tarmidzi Achmad, 2003 dalam Nusantara, 2009). Semakin besar CAR maka kinerja perbankan tersebut semakin baik, karena asset yang adaberfungsi menutupapabila terjadi kerugianpada kegiatan perkreditan dan perdagangan surat-surat berharga. Sesuai peraturan Bank Indonesia No. 10/15/PBI/2008, permodalan minimum yang harus dimiliki bank adalah $8 \%$. Suatu bank yang memiliki modal yang cukup diterjemahkan ke dalam profitabilitas yang lebihtinggi. Ini berari bahwa semakin tinggi modal yang diinvestasikan di bank maka semakin tinggi profitabilitas bank (Hayat, 2008 dalam Agustiningrum, 2012).

Non Performance

Financing(NPF) adalah rasio yang berguna untuk mengetahui kemampuan bank dalam mengukur risiko kegagalan pengembalian pembiayaan dari debitur atau pembiayaan yang tidak dapat dibayar/ditagih.Meliyanti (2009) mengatakan bahwa NPF juga dapat di katakan sabagai pembiayaan yang tidak lancar atau pembiayaan dimana debiturnya tidak memenuhi persyaratan yang diperjanjikan. NPF mencerminkan risiko pembiayaan, 
semakin kecil NPF semakin kecil pula risiko pembiayaan yang ditanggung pihak bank.

Operational Efficiency Ratio (BOPO)merupakan perbandingan antara total biaya operasi dengan total pendapatan operasi. Menurut ketentuan Bank Indonesia, BOPO merupakan perbandingan antara total biaya operasi dengan total pendapatan operasi. Efisiensi operasi dilakukan oleh bank dalam rangka untuk mengetahui apakah bank dalam operasinya yang berhubungan dengan usaha pokok bank, dilakukan dengan benar (sesuai dengan harapan pihak manajemen dan pemegang saham) serta digunakan untuk menunjukkan apakah bank telah menggunakan semua faktor produksinya dengan tepat guna dan berhasil guna (Mawardi, 2005). Dengan demikian efisiensi operasi suatu bank yang diproksikan dengan rasio BOPO akan mempengaruhi kinerja bank tersebut.

Financing to Deposit Ratio (FDR) yaitu rasio pembiayaan yang diberikan kepada dana pihak ketiga yang diterima dari bank yang bersangkutan. FDR juga memiliki fungsi yang sangat penting sebagai alat ukur yang menunjukkan besarnya ekspansi pembiayaan yang dilakukan bank maka FDR bisa digunakan alat ukur untuk melihat berfungsi tidaknya suatu intermediasi bank. Tingginya nilai FDR akan mempengaruhi keuntungan dari penciptaan pembiayaan. FDR yang meningkatmenandakanbahwa adanya penanaman dana dari pihak ketiga yang besar ke dalam bentuk pembiayaan (Adriyanti, 2011).

Bank umum syariah di Indonesia harus memperhatikan rasio FDR karena rasio ini memiliki tingkat yang sangat tinggi. Tingginya rasio FDR menandakan bahwa bank umum syariah memiliki risiko likuiditas yang cukup tinggi, karena semua dana pihak ketiga dan modal bank umum syariah disalurkan pada pembiayaan (Financing). Tingginya risiko likuiditas, dapat menyebabkan bank umum syariah tidak memiliki aset likuid untuk memenuhi kewajibannya.

Selain FDR, bank umum syariah juga harus memperhatikan NPF.NPF bank umum syariah mengalami peningkatan pada tahun 2014.Mengingat bahwa bank umum syariah menyalurkan semua dana pihak ketiga dan modalnya pada pembiayaan, sehingga kredit bermasalah semakin tinggi maka dana dari pihak ketiga dan modal akan semakin tergerus atau berkurang. Risiko ini akan mempengaruhi rasiorasio lainnya sehingga akan mempengaruhi kinerja keuangan bank umum syariah.

\section{B. Identifikasi Masalah}

1. Bank umum syariah tidak optimal dalam pengelolaan asetnya sehingga ROA mengalami fluktuatif.

2. Peningkatan rasio CAR pada bank umum syariah terjadi bersamaan dengan peningkatan beban operasional yang tidak proposional sehingga mempengaruhi profitabilitas bank umum syariah.

3. Bank umum syariah menyalurkan semua dana pihak ketiga dan modalnya pada pembiayaan, sehingga NPF atau kredit bermasalah semakin tinggi.

4. BOPO dari bank umum syariah cukup tinggi, hal ini menandakan bahwa bank umum syariah memiliki beban operasional yang jauh lebih tinggi daripada pendapatan operasionalnya.

5. Rasio FDR sangat tinggi, menandakan bahwa bank umum 
syariah memiliki risiko likuiditas yang cukup tinggi, karena semua dana pihak ketiga dan modal bank umum syariah disalurkan pada pembiayaan (Financing).

6. Kinerja keuangan bank umum syariah di Indonesia masih belum baik selama periode 2010-2016.

7. Kinerja keuangan bank umum syariah di Indonesia tidak mengalami peningkatan yang cukup signifikan selama periode 2010-2016.

\section{Pembatasan Masalah}

1. Variabel yang digunakan dalam penelitian ini adalah Capital Asset Return (CAR),Non Performing Financing (NPF), Operational Efficiency Ratio (BOPO) dan Financing To Deposit Ratio(FDR)sebagai variabel independen atau variabel bebas sedangkan Return On Asset(ROA) sebagai variabel dependen atau variabel terikat.

2. Data yang digunakan dalam penelitian ini adalah data sekunder yang diambil dari data tahunan laporan keuangan bank umum syariah yang terdaftar di Bursa Efek Indonesia periode 2010 - 2016 yang dipublikasikan disurat kabar atau internet.

3. Populasi yang digunakan dalam penelitian ini adalah perusahaan perbankan bank umum syariah yang sudah Go-Public yang ada di Indonesia dan terdaftar di Bursa Efek Indonesia sebanyak 12 bank.

4. Objek atau sampel yang digunakan pada penelitian ini adalah bank umum syariah sebanyak enam bank umum syariah yang terdaftar di Bursa Efek Indonesia periode 2010 2016 yang dipublikasikan disurat kabar atau internet.

\section{Perumusan Masalah}

1. Bagaimana tingkat kesehatan bank umum syariah?

2. Bagaimanakah pengaruh $\mathrm{CAR}$ terhadap ROA?

3. Bagaimanakah pengaruh NPF terhadap ROA?

4. Bagaimanakah pengaruh BOPO terhadap ROA?

5. Bagaimanakah pengaruh FDR terhadap ROA?

6. Bagaimana pengaruh CAR, NPF, BOPO dan FDR secara simultan terhadap ROA?

\section{TINJAUAN PUSTAKA}

\section{A. Konsep Dasar}

1. Manajemen

Menurut Koontz, (Sri wiludjeng SP 2007 : 2), manajemen adalah :

"Management is the process of designing and maintaining an environment in which individuals, working together in groups, efficiently accomplish selected aims."

Pendapat tersebut kurang lebih memiliki arti bahwa manajemen merupakan proses merancang dan memelihara suatu lingkungan di mana individu bekerja bersama di dalam kelompok, yang secara efisien memenuhi tujuan terpilih.

Menurut Daft (2010: 4), manajemen adalah :

"Manajement is attainment of organizational goals in an effective and efficient manner through planning, organizing, leading, and controlling

organizational resources."

Pendapat tersebut kurang lebih memiliki arti bahwa manajemen merupakan pencapaian tujuan organisasi dengan cara yang efektif dan efisien lewat perencanaan, pengorganisasian, pengarahan, dan pengawasan sumberdaya organisasi. 


\section{Manajemen Keuangan}

Manajemen Keuangan adalah salah satu fungsi operasional perusahaan yang sangat penting di samping fungsi operasional lainnya seperti manajemen pemasaran, manajemen operasi, manajemen sumber daya manusia, dan lain sebagainya. Manajemen Keuangan membicarakan pengelolaan keuangan yang pada dasaranya dapat dilakukan baik oleh individu, perusahaan, maupun pemerintah. Menurut Agus Sartono (2010:6) pengertian manajemen keuangan yaitu: "Manajemen keuangan dapat diartikan sebagai manajemen baik yang berkaitan dengan pengalokasian dana dalam berbagai bentuk investasi secara efektif maupun usaha pengumpulan dana untuk pembiayaan investasi atau pembelanjaan secara efisien".

\section{Kinerja Keuangan}

Pengertian kinerja menurut Indra Bastian (2006:274) adalah gambaran pencapaian

pelaksanaan/program/kebijaksanaan dalam mewujudkan sasaran, tujuan, misi dan visi suatu organisasi.Konsep kinerja keuangan menurut Indriyo Gitosudarmo dan Basri (2002:275) adalah rangkaian aktivitas keuangan pada suatu periode tertentu yang dilaporkan dalam laporan keuangan diantaranya laporan laba rugi dan neraca.

\section{Bank Umum Syariah}

a. Pengertian Bank Umum Syariah

Pengertian bank menurut UU No

7 tahun 1992 adalah badan usaha yang menghimpun dari masyarakat dalam bentuk simpanan dan menyalurkannya kepada masyarakat dalam rangka meningkatkan taraf hidup rakyat banyak. Suatu lembaga yang menghimpun dana dari masyarakat dan menyalurkan kembali ke masyarakat, dalam literature islam dikenal dengan istilah baitul mal atau baitul tamwil. Istilah lain yang digunakan untuk sebutan Bank Islam adalah bank umum syariah. Secara akademik istilah Islam dan syariah berbeda, namun secara teknis untuk penyebutan bank Islam dan Bank Umum Syariah mempunyai pengertian yang sama.

\section{Return On Asset (ROA)}

Return on Assets (ROA) merupakan salah satu rasio profitabilitas. Dalam analisis laporan keuangan, rasio ini paling sering dilihat, karena dapat menunjukan keberhasilan perusahaan dalam menghasilkan keuntungan.

ROA mampu mengukur kemampuan perusahaan manghasilkan keuntungan pada masa lampau untuk kemudian diproyeksikan di masa yang akan datang. Assets atau aktiva yang dimaksud adalah keseluruhan harta perusahaan, yang diperoleh dari modal sendiri maupun dari modal asing yang telah diubah perusahaan menjadi aktiva-aktiva perusahaan yang digunakan untuk kelangsungan hidup perusahaan.

\section{Financing To Deposit Ratio (FDR)}

Pengelolaan likuiditas merupakan masalah yang cukup kompleks dalam kegiatan operasi bank, hal tersebut disebabkan karena dana yang dikelola bank sebagian besar adalah dana dari masyarakat yang sifatnya jangka pendek dan dapat ditarik sewaktuwaktu. Likuiditas suatu bank berarti bahwa bank tersebut memiliki sumber dana yang cukup tersedia untuk memenuhi semua kewajiban (Siamat, 2005). Salah satu penilaian likuiditas bank adalah dengan menggunakanLoan to Deposit Ratio(LDR) untuk bank konvesional 
sedangkan Financing to Deposit Ratio(FDR) untuk bank umum syariah.Keduanya baik LDRatau FDR dijadikan variabel independen yang mempengaruhi ROA didasarkan hubungannya dengan tingkat risiko bank yang bermuara pada profitabilitas bank.

B. Hipotesis

$\begin{array}{rlr}\text { H1 : } & \text { Capital Adequacy } \\ & \text { Ratio(CAR)berpengaruh } \\ & \text { positif dan signifikan } \\ & \text { terhadap } \text { Return On } \\ & \text { Asset(ROA). } & \end{array}$

$\mathrm{H} 2$ : Non Performing

Financing(NPF)berpengaruh negatif dan signifikan terhadap Return On Asset(ROA).

H3 : Operational Efficiency Ratio(BOPO) berpengaruh negatif dan signifikan terhadap Return On Asset(ROA).

H4 : Financing to Deposit Ratio(FDR) berpengaruh positif dan signifikan terhadap Return On Asset(ROA).

H5 : CAR, FDR, NPF dan BOPO berpengaruh secara bersamasama (simultan) dan signifikan terhadap Return On Asset(ROA).

\section{METODOLOGI PENELITIAN}

\section{A. Tempat dan Waktu Penelitian}

\section{Tempat}

Penelitian ini dilaksanakan di Jakarta dengan mengambil data sekunder laporan keuangan dari perusahaanperusahaan perbankan Bank Umum Syariah yang terdapatdi Otoritas Jasa Keuangan (OJK)periode 2010 2016.http://www.ojk.go.id/perbankaninfo-terkini.

\section{Waktu Penelitian}

Data penelitian merupakan pooling datayaitu gabungan antara deret waktu (time series)dan cross section selama kurun waktu tahun 2010 sampai dengan tahun 2016, sehingga diperoleh jumlah observasi (titik pengamatan) sebanyak 42 yang didapat dari $6 \times 7$ (perkalian antara jumlah sampel sebanyak enam bank umum syariah dengan periode tahunan dalam tahun pengamatan).

\section{B. Populasi dan Sampel}

\section{Populasi Penelitian}

Bank umum syariah yang ada di Indonesia yang terdaftar di Bursa Efek Indonesia sampai tahun 2017 berjumlah duabelas bank diantaranya adalah PT. Bank Muamalat Indonesia tahun berdiri 1991, PT Bank Syariah Mandiri tahun berdiri 1999, PT Bank Mega Syariah tahun berdiri 2004, PT Bank BRI Syariah tahun berdiri 2008 , PT Bank Syariah Bukopin 2008, PT Bank Panin Dubai Syariah Tbk tahun berdiri 2009, B.P.D. Jawa Barat Banten Syariah tahun berdiri 2010, PT Bank Victoria Syariah tahun berdiri 2010, PT BCA Syariah tahun berdiri 2010, PT Bank BNI Syariah tahun berdiri 2010, PT Bank Maybank Syariah Indonesia tahun berdiri 2010 danPT Bank Tabungan Pensiunan Nasional Syariah tahun berdiri 2014.

\section{Sampel Penelitian}

Penentuan jumlah sampel yang akan diolah dari jumlah populasi yang banyak, memerlukan teknik sampling yang tepat. Teknik sampling merupakan teknik pengambilan sampel yang akan digunakan dalam penelitian. Adapun kriteria sampel dalam penelitian ini adalah sebagai berikut:

a. Bank umum syariah yang ada di Indonesia yang terdaftar di Bursa Efek Indonesia.

b. Bank umum syariah yang memiliki kelengkapan data berdasarkan variabel yang diteliti yang berisi rasio CAR, FDR, NPF, BOPO dan 
ROA periode pengamatan tahun 2010 sampai dengan tahun 2016.

c. Bank umum syariah yang secara rutin mempublikasikan dan menyajikan laporan keuangan tahunan selama periode pengamatan tahun 2010 sampai dengan tahun 2016.

\section{Teknik Analisis Data}

\section{Rasio Keuangan}

a. Return On Asset (ROA)

b. Capital Adequacy Ratio (CAR)

c. Non Performing Financing(NPF)

d. Operational

Efficiency Ratio(BOPO)

e. Financing to Deposit Ratio(FDR)

2. Statistik

D. Rancangan Analisis dan Uji Hipotesis

\section{Model Analisis Regresi}

a. Pendekatan Common Effect (Pooling Least Square)

Yit $=\beta 0+\beta$ Xit $+\square$ it

Dengan :

Yit $=$ Variabel dependen pada unit observasi ke- $i$ dan waktu ke- $t$

Xit $=$ Variabel independen pada unit observasi ke- $i$ dan waktu ke- $t$

$\beta=$ Koefisien slope atau koefisien arah

$\beta 0=$ Intersep model regresi

cit $=$ komponen error pada unit observasi ke- $i$ dan waktu ke- $t$

b. Pendekatan Fixed Effect

Yit $=\beta 0 \mathrm{i}+\beta \mathrm{Xit}+\square$ it,

Dengan :

Yit $=$ Variabel dependen pada unit observasi ke- $i$ dan waktu ke- $t$

Xit = Variabel independen pada unit observasi ke- $i$ dan waktu ke- $t$

$\beta=$ Koefisien slope atau koefisien arah :

$\beta 0 \mathrm{i}=$ Intersep model regresi pada unit observasi ke- $i$

cit $=$ Komponen error pada unit observasi ke- $i$ dan waktu ke- $t$

c. Pendekatan Random Effect

2. Pengujian Model

a. Uji Chow

$$
\mathrm{N}-1
$$

Uji Chow =

$$
\mathrm{NT}-\mathrm{N}-\mathrm{K}
$$

Dimana :

$\mathrm{N}=$ Jumlah data cross section

$\mathrm{T}=$ Jumlah data time series

$\mathrm{K}=$ jumlah variabel penjelas

Pengujian Uji Chow dilakukan dengan hipotesis sebagai berikut :

$\mathrm{H} 0$ : Model menggunakan pendekatan Common Effect

H1 : Model menggunakan pendekatan Fixed Effect

b. Uji Hausman

1. Uji Asumsi Klasik

a. Uji Normalitas

b. Uji Multikolinearitas

c. Uji Heteroskedastisitas

d. Uji Autokorelasi

2. Pengujian Statistik

a. Uji-t (Uji Parsial)

b. Uji-F (Uji Simultan atau bersama)

c. Koefisien Determinasi $\left(\mathrm{R}^{2}\right)$

\section{HASIL PENELITIAN DAN \\ PEMBAHASAN}

\section{A. Hasil Penelitian}

\section{Data Penelitian}

Nilai ROA dalam kurun waktu tahun 2010-2016

\begin{tabular}{|c|c|c|c|c|c|c|c|}
\hline \multirow{2}{*}{ Nama Bank } & \multicolumn{7}{|c|}{ Tahun } \\
\cline { 2 - 8 } & 2010 & 2011 & 2012 & 2013 & 2014 & 2015 & 2016 \\
\hline $\begin{array}{c}\text { PT Bank } \\
\text { Muamalat } \\
\text { Indonesia }\end{array}$ & 1.38 & 1.52 & 1.54 & 1.37 & 0.17 & 0.20 & $\mathbf{0 . 2 2}$ \\
\hline $\begin{array}{c}\text { PT Bank Syariah } \\
\text { Mandiri }\end{array}$ & 2.21 & 1.95 & 2.25 & 1.53 & 0.17 & 0.56 & 0.59 \\
\hline $\begin{array}{c}\text { PT Bank Syariah } \\
\text { Bukopin }\end{array}$ & 0.74 & 0.52 & 0.55 & 0.69 & 0.27 & 0.79 & 0.76 \\
\hline $\begin{array}{c}\text { PT Bank BRI } \\
\text { Syariah }\end{array}$ & 0.35 & 0.20 & 1.19 & 1.15 & 0.08 & 0.76 & 0.95 \\
\hline $\begin{array}{c}\text { PT Bank Mega } \\
\text { Syariah }\end{array}$ & 1.90 & 1.85 & 3.81 & 2.33 & 0.29 & 0.30 & 2.63 \\
\hline $\begin{array}{c}\text { PT Bank Panim } \\
\text { Dubai Syariah } \\
\text { Tbk }\end{array}$ & - & 1.75 & 3.29 & 1.03 & 1.99 & 1.14 & 0.37 \\
\hline
\end{tabular}

Berikut merupakan contoh perhitungan rasio keuangan ROA dengan mengambil sampel laporan keuangan pada PT Bank Muamalat Indonesia periode tahun 2016 sebagai berikut :

Rasio ROA

$=\frac{\text { Laba Sebelum Pajak }}{\text { Total Asset }}$ x 100\% 
JURNAL ILMIAH

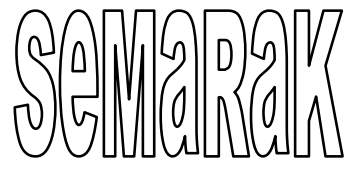

$$
\begin{aligned}
& =\frac{120 \cdot 032}{55 \cdot 851 \cdot 770} \times 100 \% \\
& =0,002149 \times 100 \% \\
& =0,2149 \% \\
& =0,22 \%
\end{aligned}
$$

Nilai CAR dalam kurun waktu tahun 20102016

\begin{tabular}{|c|c|c|c|c|c|c|c|}
\hline Nama Bank & \multicolumn{7}{|c|}{ Tahun } \\
\cline { 2 - 8 } & 2010 & 2011 & 2012 & 2013 & 2014 & 2015 & 2016 \\
\hline $\begin{array}{c}\text { PT Bank } \\
\text { Muamalat } \\
\text { Indonesia }\end{array}$ & 14.26 & 12.01 & 11.57 & 17.27 & 13.91 & 12.36 & $\mathbf{1 2 . 7 4}$ \\
\hline $\begin{array}{c}\text { PT Bank } \\
\text { Syariah } \\
\text { Mandiri }\end{array}$ & 10.60 & 14.57 & 13.82 & 14.10 & 14.76 & 12.85 & 14.01 \\
\hline $\begin{array}{c}\text { PT Bank } \\
\text { Syariah } \\
\text { Bukopin }\end{array}$ & 11.51 & 15.29 & 12.78 & 11.10 & 15.85 & 16.13 & 17.00 \\
\hline $\begin{array}{c}\text { PT Bank BRI } \\
\text { Syariah }\end{array}$ & 20.62 & 14.74 & 11.35 & 14.49 & 13.89 & 13.94 & 20.63 \\
\hline $\begin{array}{c}\text { PT Bank Mega } \\
\text { Syariah }\end{array}$ & 13.14 & 12.03 & 13.51 & 12.99 & 18.82 & 18.74 & 23.53 \\
\hline $\begin{array}{c}\text { PT Bank } \\
\text { Panim Dubai } \\
\text { Syariah Tbk }\end{array}$ & 54.81 & 61.98 & 32.20 & 20.83 & 25.69 & 20.30 & 18.17 \\
\hline
\end{tabular}

Berikut merupakan contoh perhitungan rasio keuangan CAR dengan mengambil sampel laporan keuangan pada PT Bank Muamalat Indonesia periode tahun 2016 sebagai berikut:

Rasio CAR $=\frac{\text { Modal Bank }}{\text { ATMR }} \times 100 \%$

$$
=\frac{3.682 .303}{28.903 .477} \times 100 \%
$$$$
=0,01274 \times 100 \%
$$$$
=12,74 \%
$$

Nilai NPF dalam kurun waktu tahun 2010-2016

\begin{tabular}{|c|c|c|c|c|c|c|c|}
\hline \multirow{2}{*}{$\begin{array}{c}\text { Nama } \\
\text { Bank }\end{array}$} & 2010 & 2011 & 2012 & 2013 & 2014 & 2015 & 2016 \\
\cline { 2 - 8 } & 2.51 & 1.78 & 1.81 & 0.78 & 4.85 & 4.20 & $\mathbf{1 . 4 0}$ \\
\hline $\begin{array}{c}\text { PT Bank } \\
\text { Muamalat } \\
\text { Indonesia }\end{array}$ & 3.54 & & & & & \\
\hline $\begin{array}{c}\text { PT Bank } \\
\text { Syariah } \\
\text { Mandiri }\end{array}$ & 1.12 & 0.95 & 1.55 & 2.29 & 4.29 & 4.05 & 3.13 \\
\hline $\begin{array}{c}\text { PT Bank } \\
\text { Syariah } \\
\text { Bukopin }\end{array}$ & 3.42 & 1.54 & 4.26 & 3.68 & 3.34 & 2.74 & 2.72 \\
\hline $\begin{array}{c}\text { PT Bank } \\
\text { BRI } \\
\text { Syariah }\end{array}$ & 2.14 & 2.12 & 1.84 & 3.26 & 3.65 & 3.89 & 3.19 \\
\hline $\begin{array}{c}\text { PT Bank } \\
\text { Mega } \\
\text { Syariah }\end{array}$ & 2.11 & 1.79 & 1.32 & 1.45 & 1.81 & 3.16 & 2.81 \\
\hline $\begin{array}{c}\text { PT Bank } \\
\text { Panim } \\
\text { Dubai } \\
\text { Syariah } \\
\text { Tbk }\end{array}$ & 0.00 & 0.82 & 0.19 & 0.77 & 0.29 & 1.94 & 1.86 \\
\hline
\end{tabular}

Berikut merupakan contoh perhitungan rasio keuangan NPF dengan mengambil sampel laporan keuangan pada PT Bank Muamalat Indonesia periode tahun 2016 sebagai berikut:

Rasio NPF $=\frac{\text { Pembiayaan }}{\text { Total Pembiayaan }} \times$
$100 \%$
$=\frac{303.213}{21.729 .537} \times 100 \%$

$$
\begin{aligned}
& =0,01395 \times 100 \% \\
& =1,395 \% \\
& =1,40 \%
\end{aligned}
$$

Nilai BOPO dalam kurun waktu tahun 2010-2016.

\begin{tabular}{|c|c|c|c|c|c|c|c|}
\hline \multirow{2}{*}{ Nama Bank } & \multicolumn{7}{|c|}{ Tahun } \\
\cline { 2 - 8 } & 2010 & 2011 & 2012 & 2013 & 2014 & 2015 & 2016 \\
\hline $\begin{array}{c}\text { PT Bank Muamalat } \\
\text { Indonesia }\end{array}$ & 87.38 & 85.52 & 84.48 & 85.12 & 64.81 & 97.41 & $\mathbf{9 7 . 7 6}$ \\
\hline $\begin{array}{c}\text { PT Bank Syariah } \\
\text { Mandiri }\end{array}$ & 74.97 & 76.44 & 73.00 & 84.03 & 98.46 & 94.44 & 94.12 \\
\hline $\begin{array}{c}\text { PT Bank Syariah } \\
\text { Bukopin }\end{array}$ & 93.57 & 93.86 & 91.59 & 92.29 & 96.73 & 91.99 & 91.76 \\
\hline $\begin{array}{c}\text { PT Bank BRI } \\
\text { Syariah }\end{array}$ & 98.77 & 99.56 & 86.63 & 95.24 & 99.14 & 93.79 & 91.33 \\
\hline PT Bank Mega Syariah & 88.86 & 90.80 & 77.28 & 86.09 & 97.61 & 99.51 & 88.16 \\
\hline $\begin{array}{c}\text { PT Bank Panim Dubai } \\
\text { Syariah Tbk }\end{array}$ & 182.31 & 74.30 & 50.76 & 81.31 & 82.58 & 89.29 & 96.17 \\
\hline
\end{tabular}

Berikut merupakan contoh perhitungan rasio keuangan BOPO dengan mengambil sampel laporan keuangan pada PT Bank Muamalat Indonesia periode tahun 2016 sebagai berikut :Rasio BOPO

$$
\begin{aligned}
& =\frac{\text { Biaya Operasional }}{\text { Pendapatan Operasional }} \times 100 \% \\
& =\frac{1.465 .152}{1.498 .723} \times 100 \% \\
& =0,9776 \times 100 \% \\
& =97,760026 \% \\
& =97,76 \%
\end{aligned}
$$

Nilai FDR dalam kurun waktu tahun 20102016.

\begin{tabular}{|c|c|c|c|c|c|c|c|}
\hline \multirow{2}{*}{ Nama Bank } & \multicolumn{7}{|c|}{ Tahun } \\
\cline { 2 - 8 } & 2010 & 2011 & 2012 & 2013 & 2014 & 2015 & 2016 \\
\hline $\begin{array}{c}\text { PT Bank } \\
\text { Muamalat } \\
\text { Indonesia }\end{array}$ & 91.52 & 83.94 & 94.15 & 99.99 & 84.14 & 90.30 & $\mathbf{9 5 . 1 3}$ \\
\hline $\begin{array}{c}\text { PT Bank Syariah } \\
\text { Mandiri }\end{array}$ & 82.54 & 86.03 & 94.40 & 89.37 & 81.92 & 81.99 & 79.19 \\
\hline $\begin{array}{c}\text { PT Bank Syariah } \\
\text { Bukopin }\end{array}$ & 99.37 & 93.86 & 92.29 & 100.29 & 92.89 & 90.60 & 88.18 \\
\hline $\begin{array}{c}\text { PT Bank BRI } \\
\text { Syariah }\end{array}$ & 95.82 & 90.55 & $\begin{array}{c}103.0 \\
7\end{array}$ & 102.70 & 93.90 & 84.16 & 81.42 \\
\hline $\begin{array}{c}\text { PT Bank Mega } \\
\text { Syariah }\end{array}$ & 88.86 & 83.08 & 88.88 & 93.37 & 93.61 & 98.49 & 95.24 \\
\hline $\begin{array}{c}\text { PT Bank Panim } \\
\text { Dubai Syariah } \\
\text { Tbk }\end{array}$ & 69.76 & 162.9 & $\begin{array}{c}105.6 \\
6\end{array}$ & 90.40 & 94.04 & 96.43 & 91.99 \\
\hline
\end{tabular}

(Sumber: http://www.ojk.go.id/perbankaninfo-terkini /diolah sendiri, 2017) 
Berikut merupakan contoh perhitungan rasio keuangan FDR dengan mengambil sampel laporan keuangan pada PT Bank Muamalat Indonesia periode tahun 2016 sebagai berikut :

Rasio NPF

Pembiayaan Yang Disalurkan $=\frac{\text { Total Dana Pihak Ketiga }}{x}$ 100\%

$=\frac{39.878}{41.920} \times 100 \%$

$=0,95128 \times 100 \%$

$=95,128 \%$

\section{a. Model Common Effect}

Model Common EffectVariabel CAR, NPF, BOPO dan FDR terhadap ROA

\begin{tabular}{|c|c|c|c|}
\hline \multicolumn{4}{|c|}{$\begin{array}{l}\text { Dependent Variable: ROA } \\
\text { Method: Panel Least Squares } \\
\text { Date: 07/22/17 Time: } 21: 53 \\
\text { Sample: } 20102016 \\
\text { Periods included: } 7 \\
\text { Cross-sections included: } 6 \\
\text { Total panel (balanced) observations: } 42\end{array}$} \\
\hline Variable & Coefficient & Std. Error t-Statistic & Prob. \\
\hline $\mathrm{C}$ & 6.317223 & $1.270307 \quad 4.972990$ & 0.0000 \\
\hline CAR & -0.006872 & $0.014741 \quad-0.466152$ & 0.6438 \\
\hline NPF & -0.296809 & $0.086761-3.421010$ & 0.0015 \\
\hline BOPO & -0.045605 & $0.007205 \quad-6.329589$ & 0.0000 \\
\hline FDR & -0.003382 & $0.010345 \quad-0.326963$ & 0.7455 \\
\hline R-squared & 0.708045 & Mean dependent var & 1.066429 \\
\hline Adjusted R-squared & 0.676482 & $\begin{array}{l}\text { S.D. dependent var } \\
\text { Akaike info }\end{array}$ & 1.054761 \\
\hline S.E. of regression & $0.599934 \mathrm{c}$ & riterion & 1.927349 \\
\hline Sum squared resid & 13.31706 & $\begin{array}{l}\text { Schwarz criterion } \\
\text { Hannan-Quinn }\end{array}$ & 2.134214 \\
\hline Log likelihood & $-35.47432 \mathrm{c}$ & riter. & 2.003173 \\
\hline F-statistic & 22.43294 & Durbin-Watson stat & 1.394964 \\
\hline Prob(F-statistic) & 0.000000 & & \\
\hline
\end{tabular}

Berdasarkan tabel 4.8 dengan menggunakan model common effect memiliki nilai konstanta 6,317223 sedangkan nilai koefisien regresi CAR-0,006872, NPF -0,296809, BOPO -0,045605, FDR -0,003382. Sehingga persamaan regresinya:

$\mathrm{Y}=6,317223-0,006872 \mathrm{CAR}-0,296809$ NPF - 0,045605 BOPO - 0,003382 FDR
b. Model Fixed Effect

Model Fixed Effect Variabel CAR, NPF,

BOPO dan FDR terhadap ROA

Dependent Variable: ROA

Method: Panel Least Squares
Date: 07/22/17 Time: $21: 54$

Date: 07/22/17 Time:
Sample: 20102016

Periods included: 7
Cross-sections included: 6

Total panel (balanced) observations: 4

\begin{tabular}{ccccc}
\hline \hline Variable & Coefficient & Std. Error & t-Statistic & Prob. \\
& & & & \\
\hline \hline & & & & \\
C & 6.299585 & 1.266325 & 4.974697 & 0.0000 \\
CAR & 0.003688 & 0.016343 & 0.225632 & 0.8229 \\
NPF & -0.274698 & 0.082644 & -3.323888 & 0.0022 \\
BOPO & -0.047232 & 0.006983 & -6.763874 & 0.0000 \\
FDR & -0.004175 & 0.010088 & -0.413894 & 0.6817 \\
& & & & \\
\hline \hline
\end{tabular}

Effects Specification

\begin{tabular}{|c|c|c|c|}
\hline \multicolumn{4}{|c|}{ Cross-section fixed (dummy variables) } \\
\hline R-squared & 0.806892 & Mean dependent var & 1.066429 \\
\hline Adjusted R-squared & 0.752580 & S.D. dependent var & 1.054761 \\
\hline S.E. of regression & 0.524652 & Akaike info criterion & 1.752095 \\
\hline Sum squared resid & 8.808327 & Schwarz criterion & 2.165826 \\
\hline Log likelihood & -26.79400 & Hannan-Quinn criter. & 1.903744 \\
\hline F-statistic & 14.85666 & Durbin-Watson stat & 2.085968 \\
\hline Prob(F-statistic) & 0.000000 & & \\
\hline
\end{tabular}

Berdasarkan tabel 4.9 dengan menggunakan model fixed effect memiliki nilai konstanta 6,299585 sedangkan nilai koefisien regresi CAR 0,003688, NPF -0,274698, BOPO 0,047232, FDR -0,004175. Sehingga persamaan regresinya:

$\mathrm{Y}=6,299585+0,003688 \mathrm{CAR}-0,274698$ NPF - 0,047232 BOPO -0,004175 FDR

\section{c. Model Random Effect}

Model Random Effect Variabel CAR, NPF, BOPO dan FDR terhadap ROA

Dependent Variable: ROA

Method: Panel EGLS (Cross-section random effects)

Date: 07/23/17 Time: 23:02

Sample: 20102016

Periods included: 7

Cross-sections included: 6

Total panel (balanced) observations: 42

Swamy and Arora estimator of component variances

\begin{tabular}{crrrr}
\hline \hline Variable & Coefficient & Std. Error & t-Statistic & Prob. \\
\hline \hline C & 6.297519 & 1.140145 & 5.523436 & 0.0000 \\
CAR & -0.005197 & 0.013331 & -0.389802 & 0.6989 \\
NPF & -0.289380 & 0.076780 & -3.768934 & 0.0006 \\
BOPO & -0.045866 & 0.006414 & -7.151238 & 0.0000 \\
FDR & -0.003421 & 0.009229 & -0.370697 & 0.7130 \\
\hline \hline
\end{tabular}

Effects Specification

\begin{tabular}{llrr}
\hline \hline & & S.D. & Rho \\
\hline Cross-section random & & 0.110524 & 0.0425 \\
Idiosyncratic random & & 0.524652 & 0.9575 \\
\hline \hline \multicolumn{4}{l}{ Weighted Statistics } \\
\hline \hline R-squared & 0.719426 & Mean dependent var & \\
Adjusted R-squared & 0.689094 & S.D. dependent var & 0.931512 \\
S.E. of regression & 0.576195 & Sum squared resid & 1.033367 \\
F-statistic & 23.71814 & Durbin-Watson stat & 12.28402 \\
Prob(F-statistic) & 0.000000 & & 1.506202 \\
\hline \hline & \multicolumn{2}{l}{ Unweighted Statistics } & \\
\hline \hline & 0.707868 & Mean dependent var & 1.066429 \\
R-squared & 13.32513 & Durbin-Watson stat & 1.388520 \\
Sum squared resid & &
\end{tabular}




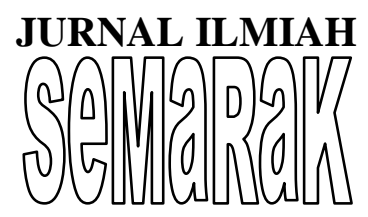

Berdasarkan tabel 4.10 dengan menggunakan model random effect memiliki nilai konstanta 6,297519 sedangkan nilai koefisien regresi CAR-0,005197, NPF -0,289380, BOPO 0,045866, FDR -0,003421. Sehingga persamaan regresinya:

$$
\begin{aligned}
\mathrm{Y}= & 6,297519-0,005197 \mathrm{CAR}- \\
& 0,289380 \mathrm{NPF}-0,045866 \\
& \mathrm{BOPO}-0,003421 \mathrm{FDR}
\end{aligned}
$$

\section{Pengujian Model Regresi Data Panel}

Model yang digunakan dalam penelitian ini adalah regresi data panel, untuk menguji spesifikasi model dan kesesuaian teori-teori dengan kenyataan. Pengolahan data dilakukan secara elektronik dengan menggunakan perangkat lunak Eviews 8.

\section{a. Uji Chow}

Uji chow dilakukan untuk mengetahui apakah model yang digunakan adalah common effect (pooled least square) atau fixed effect. Uji chow dilakukan dalam pengujian data panel dengan memilih fixed effect pada cross section panel option. Dengan ketentuan jika probabilitas > 0,05 maka kita menerima H0, berarti menggunakan pendekatan common effect (pooled least square). Tetapi jika probabilitas < 0,05, maka $\mathrm{H} 0$ ditolak, dan menerima $\mathrm{H} 1$, berarti menggunakan pendekatan fixed effect.

Untuk lebih jelasnya Uji Chow CAR, NPF, BOPO dan FDR terhadap ROA dapat dilihat pada tabel 4.11 dibawah:

Uji Chow (Uji F)Variabel CAR, NPF, BOPO

\begin{tabular}{|c|c|c|c|c|}
\hline \multicolumn{5}{|c|}{ Cross-section fixed effects test equation: } \\
\hline \multicolumn{5}{|c|}{ Dependent Variable: ROA } \\
\hline \multicolumn{5}{|c|}{ Method: Panel Least Squares } \\
\hline \multicolumn{5}{|c|}{ Date: 07/24/17 Time: 07:23 } \\
\hline \multicolumn{5}{|l|}{ Sample: 20102016} \\
\hline \multicolumn{5}{|l|}{ Periods included: 7} \\
\hline \multicolumn{5}{|c|}{ Cross-sections included: 6} \\
\hline \multicolumn{5}{|c|}{ Total panel (balanced) observations: 42} \\
\hline Variable & Coefficient & Std. Error & $\mathrm{t}$-Statistic & Prob. \\
\hline c & 6.317223 & 1.270307 & 4.972990 & 0.0000 \\
\hline CAR & -0.006872 & 0.014741 & -0.466152 & 0.6438 \\
\hline NPF & -0.296809 & 0.086761 & -3.421010 & 0.0015 \\
\hline BOPO & -0.045605 & 0.007205 & -6.329589 & 0.0000 \\
\hline FDR & -0.003382 & 0.010345 & -0.326963 & 0.7455 \\
\hline R-squared & 0.708045 & Mean dependent var & & 1.066429 \\
\hline Adjusted R-squared & 0.676482 & S.D. dependent var & & 1.054761 \\
\hline S.E. of regression & 0.599934 & Akaike info criterion & & 1.927349 \\
\hline Sum squared resid & 13.31706 & Schwarz criterion & & 2.134214 \\
\hline Log likelihood & -35.47432 & Hannan-Quinn criter. & & 2.003173 \\
\hline F-statistic & 22.43294 & Durbin-Watson stat & & 1.394964 \\
\hline Prob(F-statistic) & 0.000000 & & & \\
\hline
\end{tabular}
dan FDR terhadap ROA

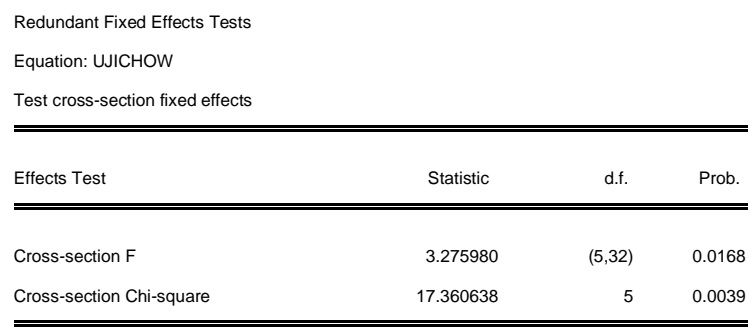

Hasil Uji Chow CAR, NPF, BOPO dan FDR Terhadap ROA pada tabel 4.11 diatas dapat terlihat bahwa nilai probabilitas cross section adalah 0,0168 atau < 0,05, maka H0 ditolak, dan H1 diterima, berarti menggunakan pendekatan fixed effect model.

b. Uji Hausman

Uji Hausman digunakan untuk menentukan apakah model yang paling tepat digunakan adalah model fixed effect atau model random effect. Dalam penelitian ini uji hausman dilakukan dalam pengujian data panel dengan memilih random effect pada cross section panel option. Dengan ketentuan jika probabilitas > 0,05 maka H0 diterima dan $\mathrm{H} 1$ ditolak, berarti menggunakan pendekatan random effect. Tetapi jika probabilitas $<$ 0,05, maka H0 ditolak dan H1 diterima, berarti menggunakan pendekatan fixed effect.

Untuk lebih jelasnya Uji Chow CAR, NPF, BOPO dan FDR terhadap ROA dapat dilihat pada tabel 4.12 dibawah: 
Uji Hausman (Uji t)CAR, NPF, BOPO dan

FDR terhadap ROA

Correlated Random Effects - Hausman Test

Equation: UJIHAUSMAN

Test cross-section random effects

\begin{tabular}{|c|c|c|c|c|}
\hline \multirow{2}{*}{\multicolumn{2}{|c|}{$\begin{array}{l}\text { Test Summary } \\
\text { Cross-section random }\end{array}$}} & \multicolumn{2}{|c|}{$\begin{array}{l}\text { Chi-Sq. } \\
\text { Statistic Chi-Sq. d.f. }\end{array}$} & \multirow{2}{*}{$\begin{array}{c}\text { Prob. } \\
0.0204\end{array}$} \\
\hline & & 11.626944 & 4 & \\
\hline \multicolumn{5}{|c|}{ Cross-section random effects test comparisons: } \\
\hline Variable & Fixed & Random & $\operatorname{Var}($ Diff.) & Prob. \\
\hline CAR & 0.003688 & -0.005197 & 0.000089 & 0.3474 \\
\hline NPF & -0.274698 & -0.289380 & 0.000935 & 0.6311 \\
\hline BOPO & -0.047232 & -0.045866 & 0.000008 & 0.6208 \\
\hline FDR & -0.004175 & -0.003421 & 0.000017 & 0.8531 \\
\hline
\end{tabular}

Cross-section random effects test equation:

Dependent Variable: ROA

Method: Panel Least Squares

Date: 07/24/17 Time: 07:28

Sample: 20102016

Periods included: 7

Cross-sections included: 6

Total panel (balanced) observations: 42

\begin{tabular}{crrrr}
\hline \hline Variable & Coefficient & Std. Error & t-Statistic & Prob. \\
\hline \hline C & 6.299585 & 1.266325 & 4.974697 & 0.0000 \\
CAR & 0.003688 & 0.016343 & 0.225632 & 0.8229 \\
NPF & -0.274698 & 0.082644 & -3.323888 & 0.0022 \\
BOPO & -0.047232 & 0.006983 & -6.763874 & 0.0000 \\
FDR & -0.004175 & 0.010088 & -0.413894 & 0.6817 \\
\hline \hline \multicolumn{5}{c}{ Effects Specification }
\end{tabular}

Cross-section fixed (dummy variables)

\begin{tabular}{lrll}
\hline \hline R-squared & 0.806892 & Mean dependent var & 1.066429 \\
Adjusted R-squared & 0.752580 & S.D. dependent var & 1.054761 \\
S.E. of regression & 0.524652 & Akaike info criterion & 1.752095 \\
Sum squared resid & 8.808327 & Schwarz criterion & 2.165826 \\
Log likelihood & -26.79400 & Hannan-Quinn criter. & 1.903744 \\
F-statistic & 14.85666 & Durbin-Watson stat & 2.085968 \\
Prob(F-statistic) & 0.000000 & & \\
\hline
\end{tabular}

Hasil Uji Haussman CAR, NPF, BOPO dan FDR terhadap ROA pada tabel 4.12 diatas, dapat dilihat bahwa nilai probabilitas cross section adalah 0,0204 atau < 0,05 maka H0 ditolak dan H1 diterima, yang berarti menggunakan pendekatan fixed effect model.

\section{Hasil Pengujian Asumsi Klasik}

Uji prasyarat analisis ini perlu dilakukan karena dalam pengujian hipotesis penelitian ini menggunakan teknik analisis regresi data panel. Uji prasyarat yang digunakan adalah uji asumsi klasik yang terdiri dari uji normalis, uji multikolinearitas, uji heterokedastisitas, dan uji autokorelasi.

a. Uji Normalitas

Uji normalitas bertujuan untuk menguji kenormalan dalam model regresi, variabel dependen dan variabel independen mempunyai distribusi normal atau tidak, maka dilakukan uji Skewness/Kurtosis tests forNormality. Model regresi yang baik adalah memiliki distribusi data normal atau mendekati normal. Tidak terpenuhinya normalitas pada umumnya disebabkan karena distribusi data yang di analisis tidak normal, karena terdapat nilai eksterm pada data yang diambil. Nilai eksterm ini dapat terjadi karena adanya kesalahan dalam pengambilan sampel, bahkan karena kesalahan dalam melakukan input data atau memang karena karakteristik data tersebut sangat jauh dari rata-rata. (Suliyanto, 2011:69). Berikut hasil uji data penelitian dengan menggunakan Uji Normalitas dapat dilihat pada gambar 4.1 dibawah ini:

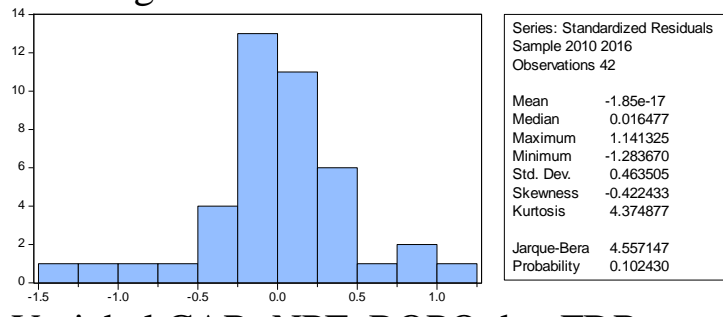

Variabel CAR, NPF, BOPO dan FDR

terhadap ROA

Pada gambar 4.1 hasil Uji Normalitas dari pengaruh variabel $\mathrm{CAR}$, NPF, BOPO, dan FDR terhadap variabel ROA menunjukkan nilai jarque-bera sebesar 4,557147. Untuk hasil analisis yang dihasilkan dari data pengolahan Uji Normalitas dilihat bahwa nilai probability $(0,102430)>$ tingkat signifikan $(0,05)$ atau $5 \%$ maka hipotesis yang digunakan dalam Uji Normalitas adalah H0 diterima dan H1ditolak maka dapat disimpulkan bahwa data dari hasil pengujian 
pengaruh variabel CAR, NPF, BOPO dan FDR terhadap ROA berdistribusi normal.

\section{b. Uji Multikolinearitas}

UjiMultikolinearitas bertujuan untuk menguji apakah model regresi ditemukan adanya korelasi antara variabel bebas yaitu CAR, NPF, BOPO dan FDR. Model regresi yang baik seharusnya tidak terjadi korelasi di antara variabel bebas karena jika hal tersebut terjadi maka variabelvariabel tersebut tidak ortogonal atau terjadi kemiripan.

Uji Multikolinearitas dilakukan dengan melihat nilai koefisien korelasinya. Untuk bisa dikatakan tidak ada multikolenieritas nilai koefisien korelasinya $<0,80$ (Gujarati,2006). Hasil uji multikolinearitas ini dapat dilihat dalam tabel berikut:

Nilai koefisien korelasi dari hasil uji multikolinearitas antara variabel CAR, NPF, BOPO dan FDR

\begin{tabular}{|c|c|c|c|c|}
\hline & CAR & NPF & BOPO & FDR \\
\hline CAR & 1.000000 & -0.456213 & 0.311006 & 0.488217 \\
\hline NPF & -0.456213 & 1.000000 & 0.012215 & -0.205100 \\
\hline BOPO & 0.311006 & 0.012215 & 1.000000 & -0.349385 \\
\hline FDR & 0.488217 & -0.205100 & -0.349385 & 1.000000 \\
\hline
\end{tabular}

Berdasarkan tabel 4.13 diatas hasil perbandingan nilai koefisien korelasi antar variabel independen,tidak ada variabel independen yang memiliki nilai koefisien korelasi > 0,80. Hal ini dapat disimpulkan bahwa model regresi dalam penelitian ini tidak terjadi multikolinearitas.

c. Uji Heterokedastisitas

Uji Heteroskedastisitas bertujuan untuk menguji apakan dalam model regresi terjadi ketidaksamaan varian dari residual satu pengamatan ke pengamatan yang lain. Jika varian tetap maka disebut Heteroskedastisitas dan jika berbeda maka terjadi problem Heteroskedastisitas. Untuk mengetahui ada atau tidaknya
Heteroskedastisitas dilakukan dengan Uji Glejser dengan indikator terjadi atau tidaknya Heteroskedastisitas.

Dalam uji Glejser akan didapat nilai absolut, jika besarnya nilai probabilitas $>$ nilai $\alpha(0,05)$ bisa dikatakan bahwa tidak terjadi heteroskedastisitas. Adapun hasil Uji Heteroskedastisitas dalam penelitian ini yang diolah dengan program Eviews 8 adalah sebagai berikut:

Uji Heteroskedastisitas dengan Metode Uji Glejser antara variabel CAR, NPF,

BOPO dan FDR terhadap ROA

Dependent Variable: RESABS

Method: Panel Least Squares

Date: 08/17/17 Time: 08:29

Sample: 20102016

Periods included: 7

Cross-sections included: 6

Total panel (balanced) observations: 42

\begin{tabular}{|c|c|c|c|c|}
\hline Variable & Coefficient & Std. Error & $\mathrm{t}$-Statistic & Prob. \\
\hline c & 1.348019 & 0.944499 & 1.427232 & 0.1619 \\
\hline CAR & 0.000146 & 0.010960 & 0.013366 & 0.9894 \\
\hline NPF & -0.016476 & 0.064508 & -0.255404 & 0.7998 \\
\hline BOPO & -0.005058 & 0.005357 & -0.944115 & 0.3512 \\
\hline FDR & -0.005272 & 0.007691 & -0.685419 & 0.4974 \\
\hline R-squared & 0.043917 & Mean dependent var & & 0.365700 \\
\hline Adjusted R-squared & -0.059444 & S.D. dependent var & & 0.433368 \\
\hline S.E. of regression & 0.446063 & Akaike info criterion & & 1.334630 \\
\hline Sum squared resid & 7.361970 & Schwarz criterion & & 1.541496 \\
\hline Log likelihood & -23.02724 & Hannan-Quinn criter. & & 1.410455 \\
\hline F-statistic & 0.424889 & Durbin-Watson stat & & 1.706170 \\
\hline Prob(F-statistic) & 0.789659 & & & \\
\hline
\end{tabular}

Bedasarkan tabel 4.14 diatas di peroleh hasil uji heterokedastisitas dengan uji Glejser untuk nilai probabilitas variabel independen CAR, NPF, BOPO dan FDR dibawah 0.05 


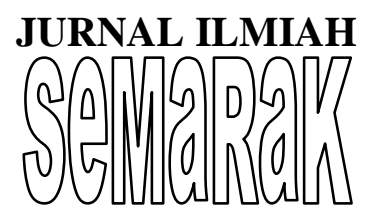

atau lebih kecil dari $\alpha=5 \%$ maka dapat

disimpulkan bahwa model regresi

mengandung permasalahan atau terjadi

Heterokedastisitas dan jika nilai probabilitas

variabel independen CAR, NPF, BOPO dan

FDR di atas 0,05 atau lebih besar dari $\alpha=5 \%$

maka dapat disimpulkan bahwa model

regresi tidak terjadi Heteroskedastisitas.

Pengujian ini dilakukan dengan menggunakan program eviews 8 yang akan memperoleh nilai probabilitas dan akan dibandingkan dengan tingkat signifikansi (alpha). Adapun ketentuan dalam memberikan kesimpulan terjadi atau tidaknya Heteroskedastisitas adalah dengan Uji Glejser dan akan didapatkan nilai absolut. Nilai probabilitas CAR sebesar $(0,9894)$, NPF sebesar (0,7998), BOPO sebesar $(0,3512)$ dan FDR sebesar $(0,4974)$. Dari hasil tabel 4.14 diatas dapat dilihat bahwa hasil uji Heteroskedastisitas dengan Uji Glejser memiliki nilai probabilitas CAR, NPF, BOPO dan FDR lebih besardari $\alpha=$ $5 \%$, maka dapat disimpulkan bahwa model regresi tersebut tidkterjadi Heteroskedastisitas..

d. Uji Autokorelasi

Menurut Suliyanto (2011:125) autokorelasi adalah adanya korelasi antara variabel itu sendiri, pada pengamatan yang berbeda waktu atau individu. Umumnya kasus autokorelasi banyak terjadi pada data time series.

Untuk menguji ada tidaknya autokorelasi tersebut biasanya digunakan uji DurbinWatson. Dalam uji ini nantinya akan diperoleh nilai Durbin-Watson yang kemudian dibandingkan dengan nilai $\mathrm{d}_{\mathrm{L}}$ dan $\mathrm{d}_{\mathrm{U}}$ dari tabel. Bila nilai $\mathrm{d}_{\mathrm{L}}<\mathrm{DW}<\mathrm{d}_{\mathrm{U}}$, maka bisa dikatakan tidak terjadi autokorelasi. Berikut ini adalah tabel Uji Autokorelasi dengan Uji Durbin Watson antara variabel CAR, NPF, BOPO dan FDR terhadap ROA. Uji Autokorelasi dengan Durbin Watson antaravariabel CAR, NPF, BOPO dan FDR terhadap ROA

\footnotetext{
Dependent Variable: ROA
}

\begin{tabular}{|c|c|c|c|c|}
\hline \multicolumn{5}{|c|}{ Method: Panel Least Squares } \\
\hline \multicolumn{5}{|c|}{ Date: 07/25/17 Time: 03:10 } \\
\hline \multicolumn{5}{|l|}{ Sample: 20102016} \\
\hline \multicolumn{5}{|l|}{ Periods included: 7} \\
\hline \multicolumn{5}{|c|}{ Cross-sections included: 6} \\
\hline \multicolumn{5}{|c|}{ Total panel (balanced) observations: 42} \\
\hline Variable & Coefficient & Std. Error & t-Statistic & Prob. \\
\hline C & 6.299585 & 1.266325 & 4.974697 & 0.0000 \\
\hline CAR & 0.003688 & 0.016343 & 0.225632 & 0.8229 \\
\hline NPF & -0.274698 & 0.082644 & -3.323888 & 0.0022 \\
\hline BOPO & -0.047232 & 0.006983 & -6.763874 & 0.0000 \\
\hline FDR & -0.004175 & 0.010088 & -0.413894 & 0.6817 \\
\hline \multicolumn{5}{|c|}{ Effects Specification } \\
\hline \multicolumn{5}{|c|}{ Cross-section fixed (dummy variables) } \\
\hline R-squared & 0.806892 & \multicolumn{2}{|c|}{ Mean dependent var } & 1.066429 \\
\hline Adjusted R-squared & 0.752580 & \multicolumn{2}{|c|}{ S.D. dependent var } & 1.054761 \\
\hline S.E. of regression & 0.524652 & \multicolumn{2}{|c|}{ Akaike info criterion } & 1.752095 \\
\hline Sum squared resid & 8.808327 & \multicolumn{2}{|c|}{ Schwarz criterion } & 2.165826 \\
\hline Log likelihood & -26.79400 & \multicolumn{2}{|c|}{ Hannan-Quinn criter. } & 1.903744 \\
\hline F-statistic & 14.85666 & \multirow{2}{*}{\multicolumn{2}{|c|}{ Durbin-Watson stat }} & 2.085968 \\
\hline Prob(F-statistic) & 0.000000 & & & \\
\hline
\end{tabular}

Berdasarkan tabel 4.15 di atas di peroleh hasil uji autokorelasi dengan uji Durbin Watson untuk nilai DW sebesar 2,085968. Diperoleh dari tabel DW untuk $n=42$ dan $k$ $=5$ nilai $\mathrm{d}_{\mathrm{L}}$ sebesar 1,2546 dan $\mathrm{d}_{\mathrm{U}}$ sebesar 1,7814. Nilai DW hitung kemudian dibandingkan dengan nilai tabel dan diperoleh $\mathrm{d}_{\mathrm{L}}<\mathrm{DW}<\mathrm{d}_{\mathrm{U}}$. Oleh karena nilai $\mathrm{DW}$ $1,2546<2,085968<1,7814$ maka dapat disimpulkan bahwa tidak terjadi autokorelasi. Dari pengujian autokorelasi pada tabel 4.15 di atas didapatkan nilai Durbin Watson hasil regresi pada penelitian ini sebesar 2,085968 yang mana nilai tersebut berada diantara 1,54 sampai dengan 2,46 sehingga sesuai dengan ketentuan pada tabel 4.14 di atas maka model regresi ini tidak terjadi autokorelasi.

\section{Pengujian Hipotesis dengan Analisa Regresi Data Panel}

a. Pengaruh Variabel CAR, NPF, BOPO dan FDR terhadap ROA Secara Parsial (Uji t)

Untuk melihat besarnya pengaruh CAR, NPF, BOPO dan FDR terhadap ROA secara parsial digunakan Uji t. Pengujian hipotesis 


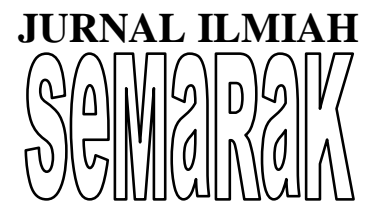

dengan analisa regresi data panel secara parsial (Uji t) ini bertujuan untuk mengetahui besarnya pengaruh masing-masing variabel independen secara individual (parsial) terhadap variabel dependen (Priyatno, 2012:58-59). Pengujian parsial atau uji $t$ digunakan untuk menguji pengaruh setiap variabel independen terhadap variabel dependennya.Seperti pengaruh CAR terhadap ROA, NPF terhadap ROA, BOPO terhadap ROA dan FDR terhadap ROA.Model regresi yang digunakan adalah model fixed effect.

Apabila nilai $\mathrm{t}$ hitung $>\mathrm{t}$ tabel, maka $\mathrm{H} 0$ ditolak dan dapat disimpulkan bahwa variabel independen berpengaruh secara nyata terhadap variabel dependennya.Apabila nilai t hitung < $\mathrm{t}$ tabel, maka H0 diterima dan dapat disimpulkan bahwa variabel independen tidak mempengaruhi variabel dependennya secara nyata. Selain itu dapat dinilai dengan indikator lain yaitu apabila probabilitas lebih kecil dari 0,05 maka hasilnya signifikan berarti terdapat pengaruh dari variabel independen secara individual terhadap variabel dependen. Apabila probabilitas lebih besar dari 0,05 maka hasilnya tidak signifikan berarti tidak terdapat pengaruh dari variabel independen secara individual terhadap variabel dependen.

1) Pengaruh CAR terhadap ROA Uji-t atau uji parsial ini menunjukkan seberapa besar pengaruh variable independen CAR terhadap variable dependen ROA.

Analisis Regresi Data Panel SecaraParsial (Uji t)

\begin{tabular}{|c|c|c|c|c|}
\hline \multicolumn{5}{|c|}{ Pengaruh CAR terhadap ROA } \\
\hline \multicolumn{5}{|c|}{ Method: Panel Least Squares } \\
\hline \multicolumn{5}{|c|}{ Date: 07/22/17 Time: 23:05 } \\
\hline \multicolumn{5}{|c|}{ Sample: 20102016} \\
\hline \multicolumn{5}{|c|}{ Periods included: 7} \\
\hline \multicolumn{5}{|c|}{ Cross-sections included: 6} \\
\hline \multicolumn{5}{|c|}{ Total panel (balanced) observations: 42} \\
\hline Variable & Coefficient & Std. Error & t-Statistic & Prob. \\
\hline C & 1.648614 & 0.415004 & 3.972525 & 0.0003 \\
\hline CAR & -0.032858 & 0.021715 & -1.513123 & 0.1392 \\
\hline
\end{tabular}

Effects Specification

\begin{tabular}{lrll}
\hline \hline \multicolumn{3}{l}{ Cross-section fixed (dummy variables) } & \\
\hline \hline & & & \\
R-squared & 0.220412 & Mean dependent var & 1.066429 \\
Adjusted R-squared & 0.086769 & S.D. dependent var & 1.054761 \\
S.E. of regression & 1.007963 & Akaike info criterion & 3.004752 \\
Sum squared resid & 35.55962 & Schwarz criterion & 3.294363 \\
Log likelihood & -56.09978 & Hannan-Quinn criter. & 3.110906 \\
F-statistic & 1.649254 & Durbin-Watson stat & 1.719522 \\
Prob(F-statistic) & 0.162994 & & \\
\hline \hline
\end{tabular}

Berdasarkan tabel 4.16 hasil pengujian analisis regresi data panel secara parsial (Uji t) menunjukkan hasil t-hitung -1,513123, tanda negatif artinya memiliki hubungan negatif atau berbanding terbalik. Sementara ttabel dengan $\alpha=5 \%(0,05)$ dan df $(\mathrm{n}-\mathrm{k})=$ $(42-5)=37$, maka t-tabel $(0,05 ; 37)=$ 2,02619 . Sehingga t-hitung lebih kecil dari ttabel $(-1,513123<2,02619)$ jadi H0 diterima sehingga dapat disimpulkan bahwa variabel independen CAR tidak berpengaruh negatifsecara nyata terhadap variabel dependen ROA. Kemudian nilai probabilitas CAR lebih besar dari konstanta $(0,1392>$ $0,05)$ maka hasilnya tidak terdapat pengaruh signifikan dari variabel independen CAR secara individual terhadap variabel dependen ROA.

\section{KESIMPULAN DAN SARAN}

\section{A. Kesimpulan}

1. Hasil penelitian ini dapat dijadikan sebagai bahan pertimbangan dalam pengambilan keputusan tentang kesehatan serta dapat menjadi cerminan untuk dapat mengambil keputusan yang tepat didalam mengelola suatu bank.

2. Berdasarkan temuan hasil penelitian maka untuk meningkatkan pendapatan maka hendaknya Bank dapat menjalankan fungsi intermediasi yaitu dengan menyalurkan pembiayaan dengan bagi hasil pihak dana ketiga lebih besar dari bunga kredit serta didukung dengan penambahan kantor 
cabang, modernisasi IT dan tenaga kerja yang handal.

3. Bank harus berusaha semaksimal mungkin agar tingkat NPF tetap berada di bawah $5 \%$ karena semakin tinggi NPF akan mengakibatkan kerugian terhadap bank.

4. Bank harus mengurangi biaya operasional/pendapatan operasional (BOPO) sehingga biaya operasional yang dikeluarkan oleh bank dapat menentukan strategi untuk berinvestasi.

5. Bank harus mampu menyalurkan pembiayaan dengan efektif, sehingga jumlah pembiayaan macetnya akan kecil dan besarnya standar FDR harus mengikuti ketentuan yang telah ditetapkan oleh Bank Indonesia antara 85\%-110\%.

6. Bagi peneliti yang hendak melakukan penelitian yang serupa dan menggunakan penelitian ini sebagai rujukan, sebaiknya membandingkan serta menggabungkan hasil penelitian ini dengan penelitian lainnya, agar menghasilkan penelitian yang lebih baik kedepannya.

\section{DAFTAR PUSTAKA}

Achmad, Tarmidzi dan Kusumo. 2003. Analisis Rasio-Rasio Keuangan sebagai Indikator dalam Memprediksi Potensi Kebangkrutan Perbankan di Indonesia.Media Ekonomi dan Bisnis, Vol 15.No.1.

Afriyanti, Meilinda, (2011). Analisis Pengaruh Current Ratio, Total Asset Turnover, Debt To Equity Ratio, Sales dan Size terhadap ROA (Return on Asset) pada perusahaan manufaktur yang terdaftar di BEI tahun 2006-2009. Skripsi, Universitas Diponegoro.

Agnes Sawir (2005:18). Analisis Kinerja Keuangan dan Perencanaan KeuanganPerusahaan. PT Gramedia Pustaka, Jakarta.
Agus Harjito dan Martono (2010:4).Manajemen Keuangan. Yogyakarta: EKONISIA.

Agus Widarjono (2007). Ekonometrika Teori dan Aplikasi.Yogyakarta : Ekonisia, FE UI.

Agus Sartono (2010:6). Manajemen Keuangan Teori dan Aplikasi ( $4^{\text {th }}$ ed). Yogyakarta: BPFE.

Ahmad Faisol, (2007:153). Analisis Kinerja Keuangan Bank Pada PT. Bank Muamalat Indonesia Tbk. Jurnal Bisnis Managemen 3(2) 1411-9366.

Almilia, L. S. dan Winny Herdiningtyas, (2005).Analisis Rasio CAMEL Terhadap Prediksi Kondisi Bermasalah Pada Lembaga Perbankan Periode 20002002,Jurnal Akuntansi dan Keuangan, Vol. 7 No.2 Nopember 2005.

Antonio, Muhammad Syafii. (2011). Bank Syariah :Dari Teori ke Praktek. Jakarta. Gema Insani Press bekerjasama dengan yayasan Tazkia Cendekia.

Arif Faizal, Eceng, dan Jaih Mubarok, Kaidah Fiqh Jinayah (2004). AsasAsas Hukum Pidana Islam. Bandung: Pustaka Bani Quraisy, Cet I.

Arni, Muhammad (2005 : 188). Komunikasi Organisasi. Jakarta: Bumi Aksara.

Bastian, Indra (2006:274). Akuntansi Sektor Publik : Suatu Pengantar. Jakarta : Erlangga.

Brigham, Eugene dan Houston (2001:90).Manajemen Keuangan $\left(8^{\text {th }}\right.$ ed). Jakarta: Erlangga.

Budisantoso Totok, Triandaru Sigit. (2005). Bank dan Lembaga Keuangan Lain.Jakarta : Salemba Empat

Daft, Richard L, (2010:4). Era Baru Manajemen, Edisi 9, Buku 2, Salemba Empat, Jakarta. 


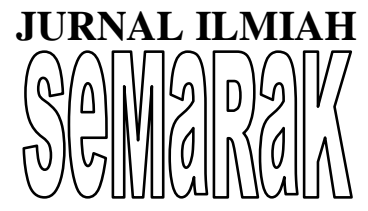

Dendawijaya, Lukman (2003). Manajemen Perbankan, Penerbit Ghalia Indonesia, Jakarta.

Ermayanti, Dwi, (2009;2). Kinerja Keuangan Perusahaan. (www.wordpress.com, diakses Januari 2017).

George R. Terry, ( Malayu S.P Hasibuan 1996: 187). Manajemen, Dasar, Pengertian, dan Masalah Edisi Revisi.Jakarta : Bumi Aksara.

G.R Terry, (Sri wiludjeng SP 2007: 92). Pengantar Manajemen, Graha Ilmu: Yogyakarta.

Gujarati, Damodar, (2006). Dasar-Dasar Ekonometrika.Jakarta: Erlangga.

Harold Kootz, (Umi Narimawati 2003: 296), Management (Eight Edition) Mc Graw Hill, International Book, Campany London.

Henry Simamora. 2004. Manajemen Sumber Daya Manusia. Edisi Ke-3.STIE YKPN.Yogyakarta.

Heri Sudarsono (2003:18). Bank Dan Lembaga Keuangan Syariah, Ekonisia, Yogyakarta.

Indriyo Gitosudarmo dan Basri (2002:275).Manajemen Keuangan. Yogyakarta:BPFE.

Irhan Fahmi (2011:2). Analisis Laporan Keuangan. Cetakan pertama.Bandung : Alfabeta.

James C, Van Horne dan Wachowicz (2005). Prinsip-prinsip

Manajemen

Keuangan.Edisi 12.Jakarta

Salemba Empat.

Juanda, Bambang dan Junaidi (2012:193).Ekonometrika Deret Waktu Teori dan Aplikasi. Bogor: IPB Press.

Kasmir, (2003). Bank dan Lembaga Keuangan Lainnya.Jakarta : PT Raja Grafindo Persada.

Koontz, (Sri wiludjeng SP 2007 : 2), Koontz, O. Donnel (1995), Management, Jakarta : PT. Gunung Agung.
Merkusiwati, Ni Ketut Lely Aryani, (2007). "Evaluasi Pengaruh Camel Terhadap Kinerja Perusahaan", Buletin Studi Ekonomi, Vol. 12, No. 1.

Mudrajat Kuncoro, (2002:285). Manajemen Perbankan Teori dan Aplikasinya,BPFE,

Yogyakarta.Nachrowi, Djalal Nachrowi, Hardius Usman. (2006;312). Pendekatan Populer dan Praktis Ekonometruka untuk Analisis Ekonomi dan Keuangan. Lembaga Penerbit Universitas Indonesia, Jakarta.

Priyatno (2012:7). Cara Kilat Belajar Analisis Data Dengan SPSS 20. Edisi Kesatu Yogyakarta : ANDI.

Purnomo, S., \& Pasaribu, V. L. D. (2019). PERGERAKAN HARGA SAHAM PT ADARO ENERGY TBK (ADRO) PADA PENGUMUMAN DIVIDEN INTERIM TAHUN BUKU 2018. Jurnal Ekonomi Efektif, 2(1).

Schaik (2001).Pengertian Bank syariah.Dari http://antoyunianto.blog.com/2010 10/18/bank-syariah/.

Septian, A.N. (2013). Faktor-faktor yang Mempengaruhi Pengungkapan Corporate Social Responsibility dalam Laporan Tahunan Perusahaan.Skripsi.STIESIA. Surabaya.

Siamat, Dahlan, (2005).Manajemen Lembaga Keuangan, Edisi Keempat, Badan Penerbit Fakultas Ekonomi Universitas Indonesia, Jakarta.

Simanjuntak, Timbul Hamonangan dan Mukhlis, Iman.(2012). Dimensi Ekonomi Perpajakan dalam Pembangunan Ekonomi. Jakarta: Raih Asa Sukses.

Sinungan, Muchdarsyah, (2000). Produktivitas apa dan Bagaimana. Jakarta: Bumi Aksara.

Riyadi (2006:161). Banking AssetsAnd Liability Management. 


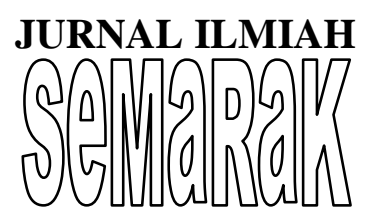

Jakarta : Fakultas Universitas Indonesia.

Stoner dan Freeman (Silalahi, 2002 :4). Pengantar Bisnis. GRAHA ILMU. Yogyakarta.

Sudana (2011).Manajemen Keuangan Perusahaan. Jakarta : Erlangga.

Sugiyono (2010:72). Metode Penelitian Kuantitatif Kualitatif dan $R @ D$. Bandung : Alfabeta.

Suliyanto, (2011:69).Ekonometrika Terapan:

Teori dan Aplikasi dengan SPSS. Yogyakarta: ANDI.

Taswan, (2006).Manajemen Perbankan. Yogyakarta: UPP STIM YPKP.

Veithzal Rivai (2007:722). Bank and Financial Institute Management. Jakarta: PT. Raja GrafindoPersada.

Wing Wahyu Winarno.(2011:102), Analisis Ekonometrika dan Statistika dengan Eviews, Edisi Ketiga.Yogyakarta : Unit Penerbit dan Percetakan (UPP STIM YKPN)

Junaidi, Titik Persentase Distribusi t, d.f. = $1-200$.

http://junaidichaniago.wordpress.c om.

Junaidi, Titik Persentase Distribusi F, Probilita $\quad=0.05$. http://junaidichaniago.wordpress.c om.

Junaidi, Tabel Durbin - Watson (DW), $\alpha=$ $5 \%$.

http://junaidichaniago.wordpress.c om.

Laporan Rasio Keuangan Triwulan Periode 2010 - 2016 PT Bank Muamalat Indonesia http://www.ojk.go.id/id/kanal/perba nkan/data-dan-statistik/laporankeuangan-perbankan/default.aspx

Laporan Rasio Keuangan Tahunan Periode 2010 - 2016 PT Bank Syariah Mandiri http://www.ojk.go.id/id/kanal/perba nkan/data-dan-statistik/laporankeuangan-perbankan/default.aspx
Laporan Rasio Keuangan Triwulan Periode 2010 - 2016 PT Bank Syariah Bukopin http://www.ojk.go.id/id/kanal/perba nkan/data-dan-statistik/laporankeuangan-perbankan/default.aspx Laporan Rasio Keuangan Triwulan Periode 2010 - 2016 PT Bank BRI Syariah http://www.ojk.go.id/id/kanal/perba nkan/data-dan-statistik/laporankeuangan-perbankan/default.aspx

Laporan Rasio Keuangan Triwulan Periode 2010 - 2016 PT Bank Mega Syariah http://www.ojk.go.id/id/kanal/perba nkan/data-dan-statistik/laporankeuangan-perbankan/default.aspx

Laporan Rasio Keuangan Triwulan Periode 2010 - 2016 PT Bank Panim Dubai Syariak Tbk http://www.ojk.go.id/id/kanal/perba nkan/data-dan-statistik/laporankeuangan-perbankan/default.aspx

$\begin{array}{llll}\text { Peraturan } & \text { BI } & \text { No. 9/1/PBI/2007 }\end{array}$ TentangPenilaian Peringkat Komposit dan Sistem Penilaian Tingkat Kesehatan Bank Umum Berdasarkan Prinsip Syariah.

SE BI No. 9/24/DPbs Tahun 2007 Tentang Penilaian Tingkat Kesehatan Bank Dipengaruhi Faktor CAMELS (Capital, Asset Quality, Management, Earnings, Liquidity, Sensitivity to Market Risk).

Undang-Undang No. 7 Tahun 1992 Tentang Perbankan. 